\title{
Ovarian dermoid cyst with teeth
}

\author{
Jan Menke, Alexander Schwarz
}

Department of Diagnostic Radiology, University Hospital, Goettingen, Germany

\section{Correspondence to}

Dr Jan Menke,

Menke-J@T-Online.de

\section{DESCRIPTION}

A 38-year-old woman presented with long-lasting dull pain that she localised in her left hip. X-ray and MRI of the hip showed a small calcification of the labrum (a ring of cartilage surrounding the acetabulum) and excluded the suspected femoroacetabular impingement (where there is abnormal contact between the acetabulum and the femoral head-neck junction). ${ }^{1}$ However, X-ray incidentally detected two teeth in the left pelvis (figure 1A, anteroposterior view; B, oblique). In the presented MRI (figure 2) the caudal tooth is outlined and an arrow indicates its central pulp. Both teeth belong to a well-demarcated round tumour of $4.5 \mathrm{~cm}$ diameter that contains much fat. This fat appears dark due to the fat-suppression of the applied proton density-weighted turbo spin-echo sequence. The tumour originates from the left ovary (figure 2, arrowheads), consistent with an ovarian dermoid cyst. After some time of consideration the woman finally decided for laparoscopic ovarian cystectomy. Histopathology confirmed an ovarian dermoid cyst and detected no malignant tumour components.

Ovarian dermoid cysts are the most common ovarian neoplasms. They are mature teratomas arising from the germ cells, and can therefore contain elements of all three germ cell layers such as epidermis, hair, calcified bone, teeth, fat and soft tissue. $^{2}{ }^{3}$ Often the tumour is asymptomatic and is detected incidentally, or is associated with unspecific symptoms. Over lifetime, malignant transformation occurs in about $1-2 \%$ of cases, mostly towards squamous cell carcinoma. ${ }^{3}{ }^{4}$ This can be prevented by ovarian cystectomy.
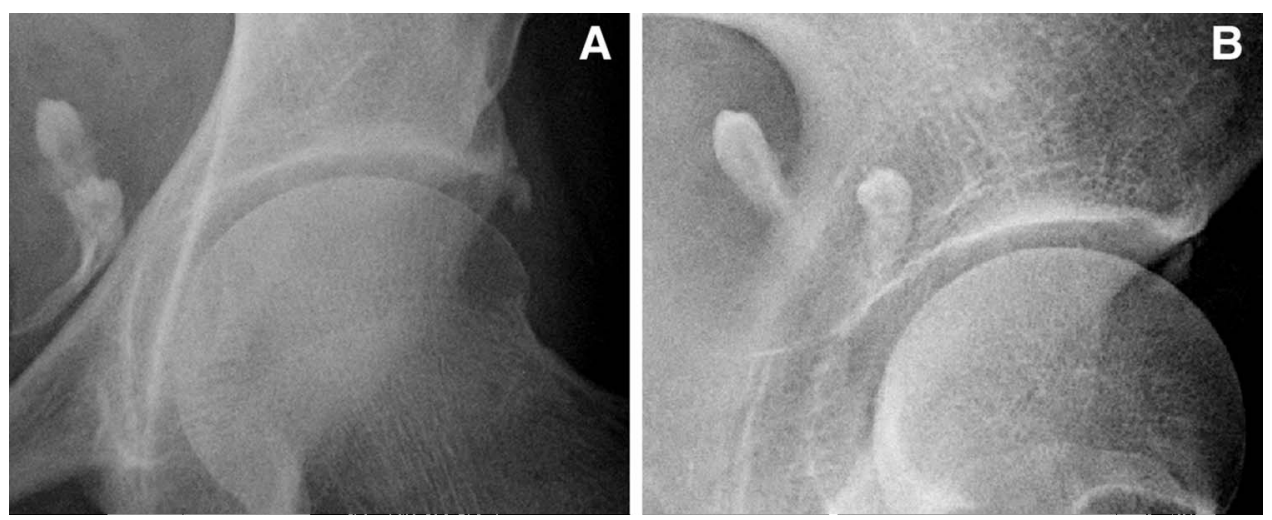

Figure 1 X-ray of the left hip ( $A$, anterioposterior; and $B$, oblique) incidentally showed two teeth in the pelvis.

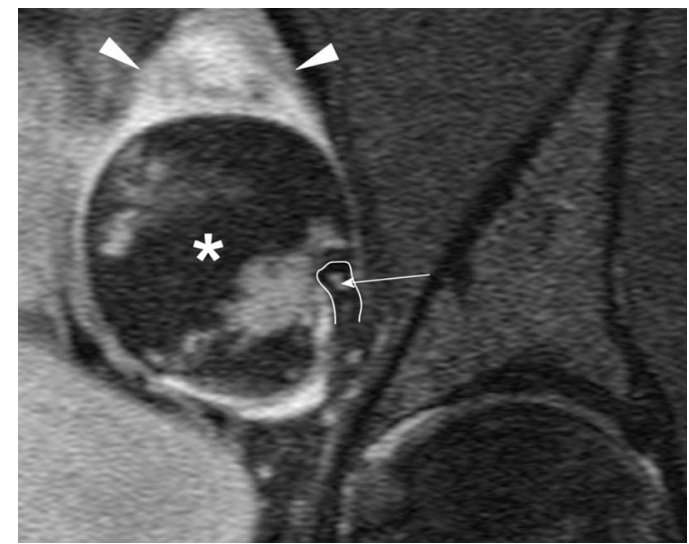

Figure 2 MRI showed a round tumour $\left({ }^{*}\right)$ originating from the left ovary (arrowheads). One of both teeth is outlined with its central pulp indicated by an arrow.

\section{Learning points}

An ovarian dermoid cyst is a mature teratoma arising from the germ cells.

- Often it is asymptomatic and is incidentally detected, for example, by teeth on a pelvic X-ray.

- Malignant transformation (about 1-2\% of cases) can be prevented by ovarian cystectomy.

Contributors JM and AS contributed to conception and design of the work, interpreted clinical data, drafted the article and revised it critically for important intellectual content, and approved the final version to be published. JM is the guarantor of the study and responsible for the overall content.
To cite: Menke J, Schwarz A. BMJ Case Rep Published online: [please include Day Month Year] doi:10.1136/bcr-2013010271 
Competing interests None.

Patient consent Obtained.

Provenance and peer review Not commissioned; externally peer reviewed.

\section{REFERENCES}

1 Dooley PJ. Femoroacetabular impingement syndrome: nonarthritic hip pain in young adults. Can Fam Physician 2008;54:42-7.
2 Outwater EK, Siegelman ES, Hunt JL. Ovarian teratomas: tumor types and imaging characteristics. Radiographics 2001;21:475-90.

3 Ozgur T, Atik E, Silfeler DB, et al. Mature cystic teratomas in our series with review of the literature and retrospective analysis. Arch Gynecol Obstet 2012;285:1099-101.

4 Gainford MC, Tinker A, Carter J, et al. Malignant transformation within ovarian dermoid cysts: an audit of treatment received and patient outcomes. Int J Gynecol Cancer 2010;20:75-81.

Copyright 2013 BMJ Publishing Group. All rights reserved. For permission to reuse any of this content visit http://group.bmj.com/group/rights-licensing/permissions.

BMJ Case Report Fellows may re-use this article for personal use and teaching without any further permission.

Become a Fellow of BMJ Case Reports today and you can:

- Submit as many cases as you like

- Enjoy fast sympathetic peer review and rapid publication of accepted articles

- Access all the published articles

- Re-use any of the published material for personal use and teaching without further permission

For information on Institutional Fellowships contact consortiasales@bmjgroup.com

Visit casereports.bmj.com for more articles like this and to become a Fellow 